\title{
Retention of the 4-pro-R Hydrogen Atom of Mevalonate at C-2,2' of Bacterioruberin in Halobacterium halobium
}

\author{
Ian E. SWIFT and B. V. MILBORROW \\ School of Biochemistry, University of New South Wales, P.O. Box 1, Kensington, N.S.W. 2033, Australia
}

\section{(Received 19 December 1979)}

\begin{abstract}
Intact cells of Halobacterium halobium fed with $(3 R, 4 R)-\left[2-{ }^{14} \mathrm{C}, 4-{ }^{3} \mathrm{H}_{1}\right] \mathrm{mevalonic}$ acid were found to incorporate label into acyclic $\mathrm{C}_{40}$ and $\mathrm{C}_{50}$ carotenoids, of which bacterioruberin was the most abundant. The ${ }^{14} \mathrm{C} /{ }^{3} \mathrm{H}$ ratios of the isolated carotenoids demonstrated that the 4-pro- $R$ hydrogen atom of mevalonic acid was retained at the $C-2$ and C-2' positions of bacterioruberin. Diphenylamine was found to inhibit the production of bacterioruberin.
\end{abstract}

The absolute configuration of the bacterial $\mathrm{C}_{30}$ $\varepsilon$-carotenoid, decaprenoxanthin (Fig. 1, I), at the polyene chain to $\varepsilon$-ring junction (C-6-S) (Andrewes et al., 1975) is the opposite to that at the equivalent position in the higher plant $\mathrm{C}_{40} \varepsilon$-carotene (C-6'-R) (Eugster et al., 1969). Recent experiments, in which $(3 R, 4 R)-\left[2-{ }^{14} \mathrm{C}, 4-{ }^{3} \mathrm{H}_{1}\right]$ mevalonic acid was incorporated into decaprenoxanthin (Fahey \& Milborrow, 1978), showed that the 4-pro- $R$ hydrogen atom of mevalonic acid was retained at C-6 of (I) as it is at C-6' of the $\mathrm{C}_{40} \beta, \varepsilon$-carotene (Goodwin \& Williams, 1965; Williams et al., 1967). Furthermore, both decaprenoxanthin and its $C_{30} \beta$-analogue, C.p. 450, (Andrewes et al., 1974), bear isoprene residues at C-2,2' that also appear to have been added with the opposite stereochemistry, at the equivalent position, of the hydrogen atom added during the cyclization of the $\mathrm{C}_{40} \beta$-analogue (Britton et al., 1977). Thus the $C_{40}$ and $C_{50}$ rings appear to have been formed by cyclases operating with opposite stereochemistry.

Bacterioruberin [2,2' -bis-(3-hydroxy-3-methylbutyl) - 3,4,3',4' - tetradehydro - 1,2,1',2' - tetrahydro$\psi, \psi$-carotene-1,1'-diol] (Fig. 1, II), the principal carotenoid of Halobacterium halobium (Baxter, 1960 ), is an acyclic $C_{50}$ compound whose structure not only suggests that it is formed by the addition of an isoprene unit to $\mathrm{C}-2,2^{\prime}$ but that it also has the same absolute configuration at these positions (J. E. Johansen \& S. Liaaen-Jensen, quoted in LiaaenJensen, 1976; Johansen \& Liaaen-Jensen, 1977) as those of the cyclic $\mathrm{C}_{50}$ carotenoids.

It was of interest, therefore, to determine whether the 4-pro- $R$ hydrogen atom of mevalonic<smiles>C/C=C\C=C(C)\C=C\C=C(C)\C=C\[C@H]1C(C)=CC[C@H](CC=C(C)CO)C1(C)C</smiles>

(I)<smiles>C/C=C/C=C(C)/C=C/C=C(C)/C=C/C=C(C)/C=C/CC(C)(C)OCC</smiles><smiles>CCCC(C)(C)O</smiles>

$\mathbf{R}^{\prime \prime}$

(ii) $R=2 \times R^{\prime}$

(iii) $R=R^{\prime}+R^{\prime \prime}$

Fig. 1. Carotenoid structures 
acid has been retained at C-2,2' during the isopentenylation of the acyclic bacterioruberin as it is during the formation of the cyclic $\mathrm{C}_{50}$ carotenoids.

\section{Experimental}

\section{Materials}

$(3 R S)-\left[2-{ }^{14} \mathrm{C}\right] \mathrm{Mevalonolactone}(17.5 \mathrm{Ci} / \mathrm{mol})$ and $(3 R, 4 R)-\left[4-{ }^{3} \mathrm{H}_{1}\right]$ mevalonolactone plus $(3 S, 4 S)$ $\left[4-{ }^{3} \mathrm{H}_{1}\right]$ mevalonolactone $(250 \mathrm{Ci} / \mathrm{mol})$ were purchased from The Radiochemical Centre, Amersham, Bucks., U.K. [U- $\left.{ }^{3} \mathrm{H}\right]$ Toluene $(124 \mu \mathrm{Ci} / \mathrm{mol})$ and [U- ${ }^{14} \mathrm{C}$ ]toluene $(23.5 \mu \mathrm{Ci} / \mathrm{mol})$ were obtained from Packard Instruments, Downers Grove, IL, U.S.A. All other reagents and solvents were the best available grade.

\section{Culture conditions}

A culture of $H$. halobium was obtained from the School of Microbiology, University of New South Wales, Sydney, Australia. It was maintained on agar slopes containing peptone (Oxoid) $(10 \mathrm{~g} / 1)$, sodium citrate $(2 \mathrm{~g} / \mathrm{l}), \mathrm{KCl}(3 \mathrm{~g} / \mathrm{l}), \mathrm{MgSO}_{4}, 7 \mathrm{H}_{2} \mathrm{O}$ $(20 \mathrm{~g} / 1), \mathrm{NaCl}(250 \mathrm{~g} / \mathrm{l})$ and agar $(15 \mathrm{~g} / \mathrm{l}), \mathrm{pH} 7.2$. The medium used was as described above without agar, and was sterilized by autoclaving for $10 \mathrm{~min}$ at $112^{\circ} \mathrm{C}$ and $60 \mathrm{kPa}$.

Bacteria were grown at $26^{\circ} \mathrm{C}$ in conical flasks shaken at 120 revolutions $/ \mathrm{min}$ on a Paton orbital incubator. Agar slopes were used to inoculate $100 \mathrm{ml}$ of sterile medium in $250 \mathrm{ml}$ flasks, which were then incubated until mid-exponential growth (4 days). Inocula were taken aseptically and transferred to fresh media containing either $\left[{ }^{14} \mathrm{C},{ }^{3} \mathrm{H}\right]$ mevalonic acid or diphenylamine; the latter was added in ethanol $(10.0 \mathrm{ml} / \mathrm{l})$ after autoclaving. The new cultures were incubated for a further 6 days, corresponding to the end of the exponential growth, before harvesting. The nominally $(3 R, 4 R)-\left[2-{ }^{14} \mathrm{C}\right.$, 4. ${ }^{3} \mathrm{H}_{1}$ ]mevalonic acid was prepared by dissolving the $\left[{ }^{14} \mathrm{C}\right]-$ and $\left[{ }^{3} \mathrm{H}\right]$ mevalonolactones, supplied as benzene solutions, in $1 \mathrm{M}-\mathrm{KOH}(2 \mathrm{ml})$ and incubating the solution at $22^{\circ} \mathrm{C}$ for $2 \mathrm{~h}$ to hydrolyse any lactone. Any organic solvent was evaporated under $\mathrm{N}_{2}$ and the aqueous mevalonic acid solution was diluted with $20 \mathrm{~mm}$-Tris/ $\mathrm{HCl}$ buffer, $\mathrm{pH} 7.8(4 \mathrm{ml})$ before being added to the medium.

\section{Extraction of carotenoids}

Cultures at stationary phase were centrifuged $\left(15 \mathrm{~min}, 0^{\circ} \mathrm{C}, 8000 \mathrm{~g}\right)$. The cell pellet was dried and weighed, then extracted in acetone $(100 \mathrm{ml})$ containing the antioxidant 2,6-di-t-butyl-4-methylphenol $(50 \mathrm{mg})$ in darkness for $18 \mathrm{~h}$. These and all subsequent manipulations were performed in dull light. The acetone cell suspension was then mixed with hexane $(100 \mathrm{ml})$ and saturated aq. $\mathrm{NaCl}(3 \mathrm{ml})$ was added until phase separation occurred. The aqueous acetone layer was extracted again with hexane $(100 \mathrm{ml})$ and the combined hexane extracts, which contained the bacterioruberin, were evaporated to dryness at $40^{\circ} \mathrm{C}$.

\section{Isolation of carotenoids}

The carotenoids were taken up in hexane $(3 \mathrm{ml})$ and applied to an activity I alumina column $(10 \mathrm{~cm} \times 25 \mathrm{~mm})$ in hexane/acetone $(4: 1, \mathrm{v} / \mathrm{v})$ eluted successively with hexane/acetone $(4: 1 . \mathrm{v} / \mathrm{v}$; $6 \times 10 \mathrm{ml}$ fractions), acetone $(8 \times 10 \mathrm{ml}$ fractions) and methanol $(4 \times 10 \mathrm{ml}$ fractions). The three fractions were stored, dry, at $0^{\circ} \mathrm{C}$ under $\mathrm{N}_{2}$ until they were redissolved in benzene and chromatographed on a Waters high-pressure liquid chromatography semi-preparative $\mu$ Porasil column (Waters Associates, Milford, MA, U.S.A. $)(4 \times 50 \mu 1$ injections) in hexane/isopropanol [99:1, 98:2 and 95:5 (v/v) for the hexane/acetone, acetone and methanol fractions, respectively; $4 \mathrm{ml} / \mathrm{min} ; 1.38 \times$ $10^{5} \mathrm{kPa}$ ] and absorbance was monitored at $440 \mathrm{~nm}$. Bacterioruberin, found in the methanol fraction, was removed from the $\mu$ Porasil column using isopropanol, and crystallized on drying. All solvents were redistilled, filtered and degassed before use.

The carotenoids were identified by their absorption spectra (Liaaen-Jensen, 1960; Davies, 1976) in the appropriate solvent. Bacterioruberin concentrations were determined using $A_{1 \mathrm{~cm}, 499}^{1 \%} 2620$ (Liaaen-Jensen, 1960; Kelly et al., 1970). In addition, chemical ionization mass spectrometry and ${ }^{1}$ H-n.m.r. spectroscopy were used to identify neurosporene (Davis et al., 1966; Davies, 1970) and bacterioruberin (Liaaen-Jensen, 1969; Kelly et al., 1970).

\section{Scintillation spectrometry}

The ${ }^{14} \mathrm{C}$ and ${ }^{3} \mathrm{H}$ present in the carotenoids were measured simultaneously by liquid scintillation counting using the methods of Milborrow (1972). Samples were counted on a Packard Tri-Carb liquid scintillation spectrometer model 2650 , which gave the following efficiencies: ${ }^{14} \mathrm{C}, 64.5 \%$; ${ }^{3} \mathrm{H}, 29.0 \%$; ${ }^{3} \mathrm{H}$ in the ${ }^{14} \mathrm{C}$ channel, $0.09 \% ;{ }^{14} \mathrm{C}$ in the ${ }^{3} \mathrm{H}$ channel, $13.15 \%$. All experimental samples were counted at least twice to confirm the absence of phosphorescence and to give less than $1 \%$ counting error. All samples were supplemented first with standard [U- $\left.{ }^{3} \mathrm{H}\right]$ toluene $(10 \mu \mathrm{l})$ and subsequently with $\left[\mathrm{U}-{ }^{14} \mathrm{C}\right]-$ toluene $(10 \mu \mathrm{l})$. Correction was then made for quenching. The quenching of the ${ }^{14} \mathrm{C}$ counts detected in the ${ }^{3} \mathrm{H}$ channel is not the same as the quenching of the ${ }^{3} \mathrm{H}$ counts in that channel or even that of the ${ }^{14} \mathrm{C}$ counts in the ${ }^{14} \mathrm{C}$ channel. This potential source of error was eliminated by reference to a calibration curve constructed from the counts of $\left[\mathrm{U}-{ }^{14} \mathrm{C}\right]$ toluene standards quenched over a range of unlabelled bacterioruberin concentrations. In addition to this 
precaution, subsamples of the $\left[{ }^{14} \mathrm{C},{ }^{3} \mathrm{H}\right]$ carotenoids were counted over a range of concentrations so that the ${ }^{14} \mathrm{C} /{ }^{3} \mathrm{H}$ ratios could be determined with different degrees of quenching.

\section{Results}

Incorporation of $(3 R, 4 R)-\left[2-{ }^{14} C, 4-{ }^{3} H_{1}\right]$ mevalonic acid into bacterioruberin

In order to study the stereochemistry of bacterioruberin biosynthesis, a cell preparation is required that incorporates labelled precursor into the carotenoid fraction with high efficiency. The susceptibility of $\boldsymbol{H}$. halobium cells to osmotic shock is well known (Marshall \& Brown, 1968) and it was found that lysis of intact cells in the low-osmotic-strength medium of Fahey \& Milborrow (1978) containing $\left[2-{ }^{14} \mathrm{C}\right]$ mevalonic acid gave a cell-free system that synthesized labelled carotenoids (I. E. Swift \& B. V. Milborrow, unpublished work). However, intact cells gave carotenoids of higher specific activity than did a lysate, and intact cells fed with labelled mevalonate gave the results shown in Table 1 . These results indicate that the ${ }^{14} \mathrm{C} /{ }^{3} \mathrm{H}$ ratio for neurosporene is almost identical with that of the mevalonate supplied. This suggests that, in $H$. halobium, carotenoid biosynthesis proceeds with the same stereochemistry, at centres derived from C-4 of mevalonate, as in other micro-organisms and higher plants (Goodwin, 1971). The ${ }^{14} \mathrm{C} /{ }^{3} \mathrm{H}$ ratio of neurosporene, therefore, was used as a base against which other ratios were compared.

The ${ }^{14} \mathrm{C} /{ }^{3} \mathrm{H}$ ratio for bacterioruberin, when normalized to that of neurosporene, remained very close to that of the $(3 R, 4 R)-\left[2-{ }^{14} \mathrm{C}, 4-{ }^{3} \mathrm{H}_{1}\right]$ mevalonic acid (10:9.78). This suggests that all the hydrogen atoms in the 4-pro- $R$ position of mevalonate are retained in bacterioruberin. The same ratio would have been obtained even if the isopentenyl residue attached to lycopene had not been derived from the same pool of added mevalonate, provided that the 4-pro- $R$ hydrogen atoms of these residues were retained. Loss of ${ }^{3} \mathrm{H}$ from any position would have lowered the ${ }^{14} \mathrm{C} /{ }^{3} \mathrm{H}$ ratio to $10: 8$ because the bacterioruberin molecule is composed of two symmetrical halves.

\section{Effect of diphenylamine upon bacterioruberin synthesis}

Diphenylamine is a potent inhibitor of bacterioruberin biosynthesis (Fig. 2); a concentration of $5 \times 10^{-6} \mathrm{M}$ decreased the amount formed by the cells to $43 \%$ of that of the control, and synthesis of bacterioruberin was abolished by $25 \mu \mathrm{M}$-diphenylamine. Cell growth was much less affected. At $5 \mu \mathrm{M}$ the cells were orange rather than their characteristic pink because of the accumulation of uncyclized $\mathrm{C}_{40}$ carotenoids. The inhibition of bacterioruberin biosynthesis by diphenylamine was overcome by thiamin $(250-1000 \mu \mathrm{g} / 1)$, but the vitamin did not restore the growth of the cells (I. E. Swift \& B. V. Milborrow, unpublished work).

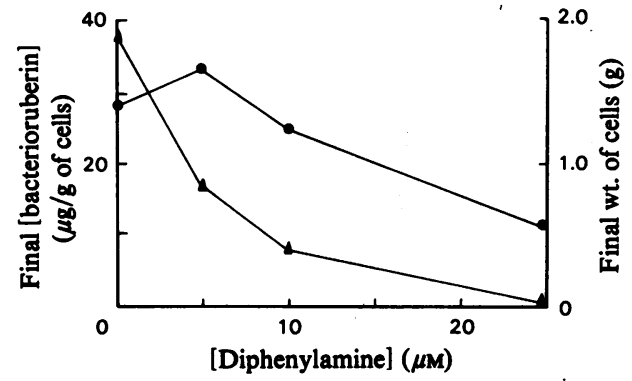

Fig. 2. Effect of diphenylamine upon growth of, and bacterioruberin concentration in, $\boldsymbol{H}$. halobium Diphenylamine in ethanol $(1.0 \mathrm{ml})$ was added to sterile media $(100 \mathrm{ml})$, which were then inoculated with exponentially growing cells and incubated for 6 days at $26^{\circ} \mathrm{C}$. $\Delta$, Final bacterioruberin concentration; $\boldsymbol{Q}$, weight of cells.

Table 1. Incorporation of $(3 R, 4 R)-\left[2-{ }^{14} \mathrm{C}, 4-{ }^{3} \mathrm{H}_{1}\right]$ mevalonic acid into bacterioruberin

$(3 R, 4 R)-\left[4-{ }^{3} \mathrm{H}_{1}\right]-+(3 S, 4 S)-\left[4-{ }^{3} \mathrm{H}_{1}\right] \mathrm{Mevalonolactone}(4.5 \mu \mathrm{Ci})$ and $\left[2-{ }^{-14} \mathrm{C}\right]$ mevalonolactone $(0.79 \mu \mathrm{Ci})$ were mixed and hydrolysed. The mevalonic acid $(5 \mathrm{ml})$ was then added to $H$. halobium medium prior to inoculation with midexponential growth cells $(0.05 \mathrm{ml})$. Cultures were incubated at $26^{\circ} \mathrm{C}$ for 6 days. The carotenoids were extracted from the cells, isolated, identified and their radioactivity was counted as described in the Experimental section.

\begin{tabular}{|c|c|c|c|c|c|c|c|}
\hline Sample & ${ }^{14} \mathrm{C}$ (d.p.m.) & ${ }^{3} \mathrm{H}$ (d.p.m.) & ${ }^{14} \mathrm{C} /{ }^{3} \mathrm{H}$ & $\begin{array}{l}\text { Observed } \\
{ }^{14} \mathrm{C} /{ }^{3} \mathrm{H} \\
\text { normalized } \\
\text { to } \\
\text { mevalonic } \\
\text { acid }\end{array}$ & $\begin{array}{c}\text { Observed } \\
{ }^{14} \mathrm{C} /{ }^{3} \mathrm{H} \\
\text { normalized } \\
\text { to } \\
\text { neurosporene }\end{array}$ & $\begin{array}{l}\text { Theoretical } \\
{ }^{14} \mathrm{C} /{ }^{3} \mathrm{H} \text { if } \\
4-p r o-R \text { of } \\
\text { mevalonic } \\
\text { acid were } \\
\text { retained at } \\
\text { all positions }\end{array}$ & $\begin{array}{c}\text { Theoretical }{ }^{14} \mathrm{C} /{ }^{3} \mathrm{H} \\
\text { if 4-pro- } R \text { of } \\
\text { mevalonic acid } \\
\text { were removed } \\
\text { from one } \\
\text { position during } \\
\text { isopentenylation }\end{array}$ \\
\hline $\begin{array}{l}\text { evalonic acid } \\
\text { eurosporene } \\
\text { cterioruberin }\end{array}$ & $\begin{array}{r}30671 \\
2280 \\
16275\end{array}$ & $\begin{array}{r}264077 \\
18856 \\
131665\end{array}$ & $\begin{array}{l}1: 8.61 \\
1: 8.27 \\
1: 8.09\end{array}$ & $\begin{aligned} 1 & : 1 \\
8 & : 7.68 \\
10 & : 9.40\end{aligned}$ & $\begin{array}{l}1: 1.04 \\
(8: 8) \\
10: 9.78\end{array}$ & $\begin{array}{c}-\overline{8: 8} \\
10: 10\end{array}$ & $\overline{\bar{Z}}$ \\
\hline
\end{tabular}

Vol. 187 


\section{Discussion}

The hydrogen atoms at C-2 and C-2' of bacterioruberin (II) have been shown by the work of Johansen \& Liaaen-Jensen (1977) to have the same absolute configuration $\left(2 R, 2^{\prime} R\right)$ as those at the analogous positions in the $\mathrm{C}_{50} \varepsilon$-carotenoid decaprenoxanthin (I) and the $\mathrm{C}_{50} \beta$-carotenoid from Corynebacterium poinsettiae. We have now shown that there is no change in the ${ }^{14} \mathrm{C} /{ }^{3} \mathrm{H}$ ratio when $(3 R, 4 R)-\left[2-{ }^{14} \mathrm{C}, 4-{ }^{3} \mathrm{H}_{1}\right]$ mevalonate is incorporated into neurosporene and bacterioruberin by $H$. halobium . We can deduce from this that the reactions involving what was C-4 of mevalonate proceed with the retention of the 4-pro- $R$ hydrogen atoms during the biosynthesis of neurosporene by this organism and that they are also retained on the isoprene unit attached to C-2 and C-2' of bacterioruberin. Most importantly the hydrogen atom at these two positions (II) must have been that which occupied the 4-pro- $R$ position in mevalonate. The 4-pro- $R$ hydrogen is retained at $\mathrm{C}-2$ in the cyclic $\mathrm{C}_{50} \varepsilon$-carotenoid decaprenoxanthin (Fahey \& Milborrow, 1978) and has now been shown to be retained during the isopentenylation of the acyclic $\mathrm{C}_{50}$ carotenoid, bacterioruberin.

A further similarity has been found between the isopentenylation reaction which forms bacterioruberin and the cyclization reactions, with and without isopentenylation, that form the cyclic $\mathrm{C}_{40}$ and $\mathrm{C}_{50}$ carotenoids. This is the sensitivity of the reactions to diphenylamine (D. Fahey \& B. V. Milborrow, unpublished work; Fig. 2) and its reversal by thiamin (I. E. Swift \& B. V. Milborrow, unpublished work). The significance of this similarity cannot be assessed until other isopentenylation reactions have been assayed.

Several analogues of bacterioruberin are known (III, IV) (Kelly et al., 1970) that lack hydroxyl groups on one or both of the attached isoprene residues. All members carry hydroxyl groups at C-1 and C-1', which suggests that hydroxylation at these positions occurs concurrently with isopentenylation.

If cyclization represents an advance from a primitive situation then this could have occurred by the exclusion of the hydroxyl oxygen from the active site and its replacement by C- 6 of the lycopene chain. It would be predicted from this that the pro- $R$ methyl group at $\mathrm{C}-1$ of bacterioruberin is derived from $\mathrm{C}-2$ of mevalonate.

We thank Dr. A Netting for help with the liquid chromatography, Mrs. E. Netting for assistance in cultivation of bacteria, Dr. A. Duffield for mass spectrometry and Mr. G. Grossman for ${ }^{1}$ H-n.m.r. spectroscopy.

\section{References}

Andrewes, A. G., Liaaen-Jensen, S. \& Borch, G. (1974) Acta Chem. Scand. Ser. B. 28, 737-742

Andrewes, A. G., Liaaen-Jensen, S. \& Weeks, O. B. (1975) Acta Chem. Scand. Ser. B 29, 884-886

Baxter, R. M. (1960) Can. J. Microbiol. 6, 417-424

Britton, G., Lockley, W. J. S., Patel, N. J., Goodwin, T. W. \& Englert, G. (1977) J. Chem. Soc. Chem. Commun. 655-656

Davies, B. H. (1970) Biochem. J. 116, 101-110

Davies, B. H. (1976) in Chemistry and Biochemistry of Plant Pigments (Goodwin, T. W., ed.), vol. 2, pp. 38-165, Academic Press, London \& New York

Davis, J. B., Jackman, L. M., Siddons, P. T. \& Weedon, B. C. L. (1966) J. Chem. Soc. C 2154-2165

Eugster, C. H., Buchecker, R., Tscharner, C., Uhde, G. \& Ohloff, G. (1969) Helv. Chim. Acta 52,1729-1731

Fahey, D. \& Milborrow, B. V. (1978) Phytochemistry 17, 2077-2082

Goodwin, T. W. (1971) in Carotenoids (Isler, O., ed.), pp. 577-636, Birkhauser-Verlag, Basel

Goodwin, T. W. \& Williams, R. J. H. (1965) Biochem. J. $97,28 c-32 c$

Johansen, J. E. \& Liaaen-Jensen, S. (1977) Tetrahedron 33, 381-383

Kelly, M., Norgard, S. \& Liaaen-Jensen, S. (1970) Acta Chem. Scand. Ser. B 24, 2169-2182

Liaaen-Jensen, S. (1960) Acta Chem. Scand. Ser. B 14, 950-952

Liaaen-Jensen, S. (1969) Pure Appl. Chem. 20, 421-448

Liaaen-Jensen, S. (1976) Pure Appl. Chem. 47, 129-145

Marshall, C. L. \& Brown, A. D. (1968) Biochem. J. 110, 441-448

Milborrow, B. V. (1972) Biochem. J. 128, 1135-1146

Williams, R. J. H., Britton, G. \& Goodwin, T. W. (1967) Biochem. J. 105, 99-105 